\title{
Utbytesstuderandes erfarenheter av slöjd på universitetsnivå
}

\author{
Pia Brännkärr
}

\begin{abstract}
Internationalisering är en viktig del av universitetens verksamhet. Inom slöjdvetenskap vid Åbo Akademi $i$ Vasa har det iakttagits en ökning när det gäller antalet utbytesstuderande med intresse att avlägga en eller flera slöjdkurser under deras utbytesperiod. För en del utbytesstuderande har slöjd varit någonting helt nytt och obekant medan andra har haft ett liknande ämne $i$ sitt hemland. Det här har väckt intresset och frågan om vad som gör lärandet och verksamheten i slöjd intressant för utbytesstuderande. Den här studiens syfte är att undersöka hurdana erfarenheter utbytesstuderande får under en slöjdkurs på universitetsnivå. Forskningsfrågan är: Vilka erfarenheter synliggör utbytesstuderande från slöjdkursen de deltagit $i$ ? Genom studien fås ett internationellt perspektiv på slöjdupplevelser, samt kunskap som hjälper mottagande universitet och lärare att i framtiden anpassa verksamheten så att studerande får bästa möjliga utbyte och erfarenhet. Det empiriska materialet består av 13 utbytesstuderandes skriftliga kursuppgifter från en slöjdkurs hösten 2018. Genom tematisk analys och med hjälp av programmet Nvivo har studerandes texter analyserats och fem teman har skapats. Det som framkommer i resultatet är att utbytesstuderandes erfarenheter berör: det personliga såsom känslor och personlig utveckling, det ämnesteknologiska såsom olika tekniker och material, den kommande lärarprofessionen, kontakten till och interaktionen med medstuderande och lärare, samt kopplingar och reflektioner till det omgivande samhället och hemlandet. Många av erfarenheterna fokuserar på det personliga och på interaktionen och kontakten med medstuderanden. Erfarenheterna berör till stor del liknande områden som framkommer i tidigare forskning.
\end{abstract}

Keywords: utbytesstuderande, erfarenhet, slöjd, universitet, slöjdutbildning

\section{Inledning}

Internationalisering är en betydande verksamhet för högskolor och universitet. Undervisnings- och kulturministeriet (2017a, 2017b) har utformat riktlinjer som ska främja internationaliseringen av finländsk högskoleutbildning och forskning 2017-2025. Ett av målen är att varje utexaminerad studerande, under sin studietid, ska erhålla erfarenhet av en internationell och mångkulturell studiemiljö.

Studerandes motiv för att åka på utbyte varierar. Det kan handla om att växa som människa och få nya erfarenheter, att förbättra sina språkkunskaper, eller om karriärutveckling och studierelaterade motiv (Hietaluoma, 2001). Det som motiverar en studerande att åka utomlands kan vara ett hinder för en annan (Nilsson, 2015). Studerande har olika förväntningar på utbytet och utbytestiden innebär att de får olika typer av erfarenheter och upplevelser som de tar med sig. För att studerande ska få ut godast möjliga erfarenheter behöver såväl mottagande institution som studerande vara medvetna om vilka utmaningar utbytesstuderande upplever vid vistelse i ett annat land och universitet (Geary, 2016).

År 2018 tog Åbo Akademi (i fortsättningen förkortat ̊̊A) emot 291 utbytesstuderanden, vars utbytesperiod varade längre än 3 månader (Vipunen, u.å.). År 2019 var motsvarande antal 260. Sedan hösten 2016 har man inom slöjdvetenskap vid Fakulteten för pedagogik och välfärdsstudier, vid ÅA i Vasa, Finland, kunnat iaktta ett ökat intresse för slöjdkurser bland utbytesstuderande. Slöjd som skolämne och slöjd överlag, kan vara helt nya och främmande fenomen för en del utbytesstuderande. I likhet med Kokko och Dillon $(2011$; 2016) kan det konstateras att det finns variation i utbytesstuderandes erfarenheter, beroende på hemlandets utbud av ett liknande skolämne. 
Utbytesstuderandes ökade intresse för kurser i slöjdvetenskap har väckt ett intresse för att utreda vad som gör att de är intresserade av slöjdkurser och hurdana erfarenheter av slöjd de har, utgående från slöjdkurser de valt att avlägga under sin utbytestid. Tidigare forskning om utbytesstuderande har till stor del fokuserat på deras förväntningar inför och erfarenheter av utbytestiden som helhet (se till exempel Costas \& Singco, 2016; Garam, 2001; Hietaluoma, 2001; Nilsson 2015). Samtidigt har tidigare forskning inom slöjd till stor del fokuserat på vad personer som är uppväxta med skolämnet har för upplevelser av, och tankar om slöjden och lärande i slöjd (se till exempel Hartvik, 2013; Pöllänen \& Vartiainen, 2013; Westerlund, 2015). Till viss del finns det även forskning om utbytesstuderande och slöjd, och som till stor del utgår från och fokuserar på det kulturella och kulturarvet (se till exempel Kokko \& Dillon 2011; 2016; Kröger 2012; 2020). Temat är ändå förhållandevis lite beforskat. Genom att beforska temat erfarenheter och upplevelser av slöjd utgående från utbytesstuderande fås ett internationellt perspektiv på slöjdupplevelser.

Syfte med studien är att undersöka hurdana erfarenheter utbytesstuderande får under en slöjdkurs på universitetsnivå. En närmare beskrivning av kursen ges i samband med att det empiriska materialet presenteras. Utgående från syftet har följande övergripande forskningsfråga formulerats:

- Vilka erfarenheter synliggör utbytesstuderande från slöjdkursen de deltagit i?

Forskningsfrågan är brett formulerad eftersom det är av intresse att se på helheten och att närma sig temat och det empiriska materialet med ett öppet sinne. Studien bidrar med kunskap om utbytesstuderandes erfarenheter av studier under sin utbytesperiod. Kunskapen möjliggör för mottagande universitet och lärare att $\mathrm{i}$ framtiden anpassa verksamheten så att studerande får bästa möjliga utbyte och erfarenhet.

I denna studie används begreppet utbytesstuderande när det handlar om studerande som för en kortare period studerar i ett annat land. Begreppet internationella studeranden innefattar även studeranden som studerar en längre tid i ett annat land, möjligen med syfte att avlägga examen.

\section{Tidigare forskning}

\section{Erfarenhet av utbytesstudier}

Studerande som åker på utbyte har olika förväntningar inför sin studietid. Förväntningarna är både personliga och akademiska (Hietaluoma, 2001; Nilsson, 2015). Studerande önskar öka självförtroende och självständighet (Costas \& Singco, 2016; Hietaluoma 2001), stärka sociala färdigheter, utveckla sin kommunikationsförmåga och skapa nya kontakter genom att hitta vänner främst bland lokala studeranden, men också bland studerande från andra länder (Costas \& Singco, 2016; Hietaluoma, 2001; Sato \& Hodge, 2015). Att utvecklas som människa är sådant som utbytesstuderande upplever att uppfylls (Nilsson, 2015). Förväntningen om att utveckla sina språkkunskaper kan ha kopplingar både till studier och till det personliga. Att lära sig om främmande kulturer, att få förståelse för olika kulturer och att bekanta sig med landet där studerandena befinner sig är andra exempel på förväntningar som finns (Costas \& Singco, 2016; Hietaluoma, 2001).

Även erfarenheterna från utbyte berör både det personliga och det akademiska planet. I samband med att studier utomlands inleds, sker olika typer av anpassningar och studerande möter utmaningar som hör ihop med akademisk anpassning (Mesidor \& Sly, 2016). De akademiska erfarenheterna hänförs främst till studierna, relationer i samband med studierna och kurser som studerande valt att avlägga. Forskning visar att internationella studerande fått utstå negativa kommentarer från lärare, som önskat att de avbryter kurser på grund av antagandet att studerandes språkkunskaper är bristfälliga (Sato \& Hodge, 2015). Det här resulterade i att studerande hade svårt att skapa en positiv relation till lärarna. Hietaluoma (2001) och Garam (2001) lyfter fram positiva erfarenheter av relationer. Utbytesstuderande har upplevt både personal och andra studerande som hjälpsamma (Hietaluoma, 2001). Garam (2001) lyfter fram att utbytesstuderande som vistats i Finland upplevde förhållandet till personalen som icke-formell och 
tröskeln till att kontakta personalen var låg. Forskning visar att internationella studerande ofta har svårigheter med att skapa sociala kontakter till lokala studerande och ortsbefolkning, samt svårigheter att införlivas i den lokala kulturen och det lokala studielivet (Garam, 2001; 2018; Hietaluoma, 2001; Sato \& Hodge, 2015). Däremot är det lättare att få vänner bland andra utbytesstuderande (Garam, 2001; 2018). Garam (2001) lyfter fram att för utbytesstuderande ordnas ofta eget program, vilket gör att de främst rör sig bland andra utbytesstuderande. Samtidigt är kurserna som de avlägger ofta på engelska, vilket kan innebära att det inte är många lokala studeranden på samma kurser. Bristen på kontakt med lokala studeranden ses ofta som det största misslyckandet i samband med utbytestiden (Garam, 2001).

Andra exempel på akademiska utmaningar är att studerande på grund av sina begränsade språkkunskaper kan missförstå innehåll i föreläsningar (Sato \& Hodge, 2015). Sato och Hodge (2015) lyfter fram att studerande kan behöva kämpa för att klara av examination och att erhålla höga betyg. Andra språkproblem som studerande upplevt i samband med kurser är att lärarens språkkunskaper kan vara bristfälliga, eller att engelsk litteratur inte finns att tillgå (Garam, 2001). Hellstén och Prescott (2004) tar i sin tur upp en aspekt där föreläsare förenklar sin engelska för att internationella studeranden bättre ska förstå. Det här agerandet strider mot de studerandes förväntningar om att förbättra sina språkkunskaper under studietiden utomlands. Det här kan också resultera i att internationella studeranden känner sig ytterligare marginaliserade från nationella studeranden (Hellstén \& Prescott, 2004). I samband med gruppdiskussioner kan utbytesstuderande uppleva att de är isolerade, i och med svag interaktion med och svagt stöd från lokala studerande (Sato \& Hodge, 2015). Förutom den här typen av språkproblem kan utbytesstuderande uppleva språkproblem på fritiden (Garam, 2001). Det handlar oftast om vardagssituationer som försvåras av den egna ofullständiga språkkunskapen.

Sato och Hodge (2015) synliggör att kulturella skillnader mellan hemlandet och det mottagande landet kan vara en inverkande faktor vid upplevda studiesvårigheter. Det kan exempelvis handla om att studerande är vana att i hemlandet acceptera, anpassa och memorera det som en lärare säger, samtidigt som de har få chanser till att uttrycka egna åsikter. En undervisningskultur där ifrågasättande av auktoriteter, kritiskt tänkande och egna åsikter gynnas, kan kännas främmande. Det här medför i sin tur att utbytesstuderande upplever sig var exkluderade från diskussionsmiljön. Utbytesstuderandes erfarenheter varierar beroende på personliga olikheter i bland annat utbildning, social integration, metoder att söka hjälp, utvecklande av vänskap, olika kommunikationsstilar och vanor, samt karriärsval (Bista, 2019).

\section{Erfarenhet av slöjdundervisning}

I tidigare forskning (Kokko \& Dillon 2011; 2016) framkommer att utbytesstuderande, som deltagit i slöjdkurser vid ett finländskt universitet, uttryckt förvåning över den status, uppskattning och kvalité som slöjden har både i grundskolor och i lärarutbildningen. Slöjden värderas inte lika högt i utbytesstuderandes hemländer. Den låga uppskattningen antas hänga ihop med att det som ses som ickeakademiska ämnen inte värderas lika högt som andra ämnen. Forskningen visar även att utbytesstuderande upplevt slöjdundervisningen i hemländerna som dålig. Där beror undervisningens kvalité mycket på den individuella lärarens intresse och kunskap i ämnet. Vidare framkommer det att utbytesstuderanden, under sin tid i Finland, insåg vad de saknat i hemlandet. De uttryckte en önskan om att slöjd i högre grad skulle undervisas i deras hemländer.

Kröger (2020) lyfter fram att en kurs om kulturarv och slöjdutbildning (Cultural Heritage and Craft Education) kan vara meningsfull för utbytesstuderande. Krögers fokus var att undersöka vad utbytesstuderande ser som betydelsefull inlärning (significant learning) i en kulturell slöjdkurs, samt hur en kulturell dialog är närvarande i beskrivningarna av betydelsefull inlärning. Det som lyfts fram är bland annat att studerande bryr sig om slöjd, kulturarv och kulturell dialog. Positiv interaktion utgjorde en viktig del av hur meningsfull studerande ansåg att deras inlärningserfarenheter var. Studerande värdesatte inlärning i blandade grupper, och samarbete och interaktionen med andra sågs som betydelsefulla erfarenheter av inlärning. Även att veta hur man kan tillämpa innehåll från kursen var 
framträdande när studerande beskrev sina erfarenheter. Vidare framkommer det att kulturarv som kommer i uttryck genom slöjd är en meningsfull tillgång för undervisning och det stöder en kulturell dialog.

Kröger (2012) framhåller hur slöjd kan fungera som ett bra redskap för läraren för att möjliggöra mångkulturell kommunikation och för att förstå skillnader. Vidare lyfter hon fram att kommunikationen mellan personer med olika bakgrunder kan underlättas med hjälp av ett konkret slöjdföremål. En viktig del av slöjdundervisningen och verksamheten i slöjd är kommunikation (Andersson \& Johansson, 2017; Degerfält \& Porko-Hudd, 2008; Hartvik, 2013; Illum \& Johansson, 2009). Kommunikationen som sker i samband med slöjdverksamhet är inte endast verbal kommunikation, utan det kan exempelvis vara icke-verbal kommunikation som kroppsspråk och gester. Att kommunikationen i slöjd inte enbart handlar om verbal kommunikation är också det som stöder tanken om att utbytesstuderande får, och kan delta i slöjdkurser. Även om kursspråket är svenska har de möjlighet att klara av att genomföra kurserna. Genom kommunikationen kan annat än slöjdspecifikt innehåll läras ut (Oja, Sjöberg \& Johansson, 2014). Lärande i slöjd innefattar att planera och formge föremål, gestalta olika saker, handla i vardagliga situationer och att lära andra. Lärande sker dessutom i en social och kulturell situation, och det handlar inte endast om att arbeta på det egna slöjdarbetet (Andersson \& Johansson, 2017). Själva kontexten för slöjdundervisningen erbjuder och skapar också olika typer av erfarenheter. Exempelvis i en kontext där det handlar om hobbyverksamhet för vuxna visar forskning (Kouhia, 2015) att slöjdverksamheten skapar erfarenhet av ömsesidig verksamhet, aktivt deltagande, social interaktion och delat ansvar. Kouhia (2015) lyfter fram att slöjdande ses som ett mycket bredare fenomen än endast bearbetning av material.

Klasslärarstuderandes erfarenheter av lärande i samband med ett grupprojekt i slöjd, som genomförts i en grundkurs för klasslärarstuderanden, har analyserats av Pöllänen och Vartiainen (2013). Grupprojektet ökade studerandes kunskaper och färdigheter inom flera områden, som är relevanta för deras kommande lärarprofession. Studerande upplevde att de utvecklats inom områden som projektbaserat och elevcentrerat lärande, samspel mellan undervisning och inlärning, formgivning, samarbete, grupparbete och kommunikation, problemlösning och självstyrning, samt reflektiv förmåga. Huovila och Rautio (2008) lyfter fram färdigheter i undervisningsplanering, samt didaktiska och pedagogiska tankar och färdigheter som aktuella områden för att som lärare kunna sätta upp mål, planera undervisningen och granska genomförandet av undervisningen. Vidare lyfter de fram att en del av slöjdundervisningen handlar om individens välmående och tillväxt, vilket bland annat innebär att känna glädje och tillfredsställelse över sitt arbete, och om att självkänslan växer. Genom samarbetsuppgiften i slöjd började klasslärarstuderande förstå meningen med att använda ett sådant arbetssätt i undervisningen (Pöllänen \& Vartiainen, 2013). De fick även erfara att samtidigt som samarbete kan vara användbart, kan det vara krävande. Vidare fick studerande insikt om att deras olika bakgrunder och färdigheter var en tillgång vid genomförandet av projektet. Samarbetet med både lärare och medstuderande stödde deras utvecklingsprocess och deras möjlighet att nå en ny kompetensnivå. Genom att vara involverade i lärandeprocessen och problemlösningen ökade deras lärande. Att samarbeta fungerade motiverande för studeranden som redan hade kunskap, samtidigt som det sänkte tröskeln för studeranden som var nervösa över sina egna svaga kunskaper. Upplägget med ett grupprojekt i slöjd medförde att studerande började jämföra det med sina egna erfarenheter från skolslöjden. Den här typen av uppgift gav studerande erfarenhet av ett lärande som både var innehållsrikt och mindre traditionellt, vilket framkallade nyttiga reflektioner hos dem.

\section{Metod och genomförande}

\section{Metod och empiriskt datamaterial}

Studien är hermeneutisk, eftersom den handlar om att tolka och förstå upplevelser av ett fenomen; utbytesstuderandes erfarenheter under en slöjdkurs (Anttila, 2005; Westlund, 2019). I hermeneutik är det lämpligt att använda ett empiriskt material som gett respondenterna utrymme att uttrycka sina erfarenheter och upplevelser utan för stark styrning från forskaren (Westlund, 2019). Studiens empiriska material består av utbytesstuderandes skriftliga kursuppgifter från kursen Slöjdkunnande, fem ECTS. 
Tack vare att jag var en av två lärare på kursen, har jag ett insidesperspektiv och intresse för temat. Det empiriska materialet samlades in efter kursens slut hösten 2018. Kursen ingick i grundstudierna under det första studieåret inom slöjdvetenskap. Kursinnehållet hade sådan karaktär att mycket handlade om individuellt arbete och reflektioner. Utbytesstuderande fick handledning och uppgiftsbeskrivningar på engelska. På kursen deltog totalt 24 studerande, av vilka 17 var utbytesstuderande från 7 olika länder i Europa, Asien och Amerika. Tretton utbytesstuderande gav tillåtelse att använda deras inlämnade texter i forskningssyfte. Texterna består av reflektioner kring arbetsområden och slöjduppgifter, dokumentation av genomförda slöjdprocesser, samt reflektioner över vad studerande lärt sig i relation till hemländernas läroplansbeskrivningar och målsättningar för skolan. I den här studien redogörs inte för respondenternas hemländer, eftersom det inte är av relevans för studien. Dessutom är antalet utbytesstuderande per termin vid ÅA i Vasa lågt, vilket medför att det kan bli lätt att identifiera specifika utbytesstuderanden om hemlandet framkommer. Nedan följer en noggrannare beskrivning av kursens innehåll, mål och temaområden.

Kursen bestod av ungefär 50 timmar kontaktundervisning och pågick från början av september till slutet av oktober. Kursens lärandemål och innehåll var följande:

De studerande ges möjlighet att uttrycka sitt personliga slöjdkunnande genom användning av grundläggande material och tekniker. De studerande bekantar sig med och diskuterar slöjdämnets pedagogiska möjligheter i fostran och utbildning. Kursens syfte är även att skapa beredskap och intresse för att fortgående fördjupa sina kunskaper om slöjd som läroämne.

Vid slutbedömning av kursen skall studeranden kunna:

- tillämpa vissa grundläggande ämnestekniker

- föra ett läroplansförankrat resonemang om slöjdämnet i skolan

- dokumentera och föra en teorigrundad diskussion över egen genomförd slöjdprocess

(Studiehandboken, u.å.)

Kursupplägget bestod av fyra temaområden samt en avslutande reflektion. När kursen avslutades skulle studerande sammanställa sitt arbete och lämna in det. För varje temaområde fanns det angivet vad som behövde ingå i inlämningen. Det handlade om produkter, planeringar och reflektioner. Första temaområdet fokuserade på introduktion till slöjdverksamhet och enkla knyttekniker. Här krävdes inga skriftliga reflektioner. Andra temaområdet utgjordes av två delar. Första delen var en utedag vid en vandringsled. Studerande skulle på ett konkret sätt bekanta sig med uteundervisning, videslöjd och täljning. Andra delen bestod av arbete med broderi och bleckplåt. Temaområdet avslutades med ett tillfälle då bleckplåtsarbetena användes i samband med bakning. Studerande fick då en inblick i hur slöjd kan samverka med andra skolämnen. Avslutningsvis skulle studerande skriftligt reflektera kring temaområdets alla delar. Det tredje temaområdet hade rubriken "I sagornas värld" och studerande skulle planera och tillverka en produkt med inspiration från en saga, bok eller film. De skulle producera skisser och följa upp och reflektera kring sin egen slöjdprocess. I reflektionen ombads de beskriva åtminstone följande saker: The idea behind the product and how it's connected to the fairy tale you have chosen, what techniques and materials you have used and why you've made the choices you've done och what you have learnt during the theme. Studerande fick relativt fritt välja vilka tekniker och material som de främst ville arbeta med och fördjupa sig i. Efter behov handledde lärarna studerande i deras val. Det här var aktuellt speciellt för utbytesstuderande som hade begränsade erfarenheter av slöjd eller liknande ämnen. Det fjärde temaområdet var ett grupparbete där utbytesstuderande blandades i grupper med finländska studerande. Varje grupp bestod av 4-5 studeranden. Uppgiften var att studerande skulle utveckla sina kunskaper i att forma i trä, samt att kombinera tekniker och material från textilslöjd och teknisk slöjd. Varje grupp skulle planera och tillverka en produkt, där både formning i trä och textila material ingick. Samarbetet var också en viktig del. Avslutningsvis skulle de individuellt skriftligt reflektera över sitt och gruppens arbete. Som hjälp till den här reflektionen hade de följande frågor: How did you solve problems? What are your thoughts about the teamwork? What have you learnt by working and solving problems together? och Other thoughts? Den avslutande reflektionen för kursen var att 
studerande skulle bekanta sig med läroplanen för grundläggande utbildning i sitt hemland. Med den som grund skulle de reflektera kring sitt lärande under hela slöjdkursen. Studerande skulle identifiera vilka mål i hemlandets läroplan de anser sig ha uppfyllt under slöjdkursen, samt diskutera på vilket sätt målen uppfyllts.

De skriftliga reflektioner som ingick i temaområdena utgör denna studies empiriska material. Längden på texterna varierar från fyra till tolv sidor och dessa lämnades in i fysiskt format. De inlämnade texterna skannades in och sparades som PDF-filer. Texterna har inte språkgranskats och de används i sin ursprungliga form i kommande citat. Tanken om att använda studerandes texter i forskningssyfte kom till först efter att dokumentationerna var insamlade. Det här betyder att texterna inte påverkats av att de utgör en del av ett forskningsmaterial (Sjöberg, 2009). Det empiriska materialet utgörs av kursuppgifter från en kurs, där respondenterna var medvetna om att kursprestationerna kommer att bedömas. Även om deltagarna uppmanades reflektera över såväl positiva som negativa erfarenheter finns det en risk att respondenterna valt att mestadels lyfta fram positiva upplevelser. När analysarbetet började kunde eventuella brister i materialet inte kompletteras, eftersom kontakten till respondenterna inte längre fanns (jfr. Anttila, 2005; Sjöberg, 2009). Ytterligare en aspekt gällande det empiriska materialet är att majoriteten av respondenterna använt ett annat språk än sitt modersmål då de sammanställt sina erfarenheter. Dels innebär det här att det förekommer en del skrivfel i texterna, dels kan det innebära att alla tänkta nyansskillnader inte framkommer i reflektionerna. Forskarens modersmål är inte heller engelska, vilket betyder att det även hos forskaren sker en tolkning av texter på ett främmande språk. Kulturella skillnader påverkar också tolkningen. Olika begrepp kan tolkas på olika sätt beroende på kontexten och en persons bakgrund och förförståelse för ett ämne (Sjöberg, 2009).

\section{Analys av datamaterial}

Texterna har analyserats med hjälp av tematisk analys. Respondenterna benämns Studerande 1-13 och förkortas S1-S13 i samband med citat. Tematisk analys består av sex olika faser, men det handlar ändå inte om en linjär process, utan forskaren förflyttar sig enligt behov fram och tillbaka mellan de olika faserna som ingår i analysprocessen (Braun \& Clarke, 2006). Den hermeneutiska processen kan beskrivs som cirkulär eller spiralformad och där handlar det också om att pendla mellan del och helhet (Alvesson \& Sköldberg, Anttila, 2005; Westlund, 2019). Vid tematisk analys kan ett dataprogram underlätta kodningen (Joffe \& Yardley, 2004). Programmet Nvivo 12 plus användes för att göra databearbetningen så överskådlig som möjligt. Med hjälp av programmet var det lätt att koda texterna, att få en överblick över samtliga koder och att gruppera dem i olika teman. I analysarbetet var förhållningssättet inledningsvis induktivt, i det avseendet att skapandet av koder inte utgick från en färdig teoretisk modell, utan respondenternas texter lästes, kodades och analyserades med ett öppet sinne. Som utbildad och verksam inom slöjdområdet fanns det ändå hos mig en förförståelse och insyn i slöjdämnet och dess teorier. Datamaterialet samlades in från en kurs där jag själv var lärare, vilket medför att jag hade en viss förkunskap om materialet. Att forskaren har en förkunskap om materialet medför att det kan finnas några inledande analytiska intressen eller tankar (Nowell, Norris, White \& Moules, 2017). Inom hermeneutiken kan forskarens möjlighet att se vad materialet innehåller öka, genom att ha medvetandegjort den egna förförståelsen och genom att ha en "genuint nyfiken hållning" till vad det empiriska materialet innehåller (Westlund, 2019, s. 82).

Den tematiska analysens första fas handlar om att bekanta sig med datamaterialet och ställa frågor för att få inledande idéer om datamaterialets innehåll (Braun \& Clarke, 2006). Även inom hermeneutiken handlar det om att ställa frågor till texten, och frågor är sådana som utgår från förförståelse (Alvesson \& Sköldberg, 2008). I fasen skapades tre frågor som fungerade som stöd för den fortsatta kodningen: vad upplever utbytesstuderade som utmärkande med slöjd, vad upplever utbytesstuderande att de lärt sig under slöjdkursen och vilka övriga upplevelser har utbytesstuderande av slöjdkursen? Frågorna utgick från forskarens förförståelse och förkunskap om materialet. Andra fasen är att skapa inledande 
koder och påbörja kodningen av datamaterialet. I det här skedet skapades totalt 18 koder. När allt datamaterial kodats, påbörjades fas tre som handlar om att hitta teman genom att gruppera koderna. Vid skapandet av teman kom forskarens förförståelse till större grad in i bilden. Det induktiva förhållningssättet som använts vid kodningen fick ge rum för ett mer deduktivt förhållningssätt.

Med utgångspunkt i en modell för slöjdverksamheten utformad av Lindfors (1991), samt Hartviks (2013) tillämpning av modellen, skapades fem olika teman: studerandes egenvärld, teknologisk-estetisk värld, kommande lärarens egenvärld, medvärld och omvärld (se även Ahlskog-Björkman, 2007; PorkoHudd, 2005). Lindfors (1991) modell består av fyra aspekter: individrelaterad aspekt som också benämns slöjdarens egenvärld, teknologi-estetikrelaterad aspekt som benämns teknologisk-estetisk värld, situationsrelaterad aspekt som benämns medvärld och omgivningsrelaterad aspekt som benämns omvärld. Hartviks (2013) tillämpning av modellen innehåller utöver Lindfors fyra aspekter också aspekten lärarens egenvärld. Modellen innefattar alltså den som slöjdar, de material och tekniker som används, själva slöjdsituationen, samt personerna som medverkar och samhället i vilket verksamheten finns (Hartvik, 2013). I denna studie har lärarens egenvärld utvecklats vidare till kommande lärarens egenvärld. I kodningsfasen framkom utsagor som berör respondenternas tankar och insikter inför att de själva ska arbeta som lärare, därför utkristalliserades temat kommande lärarens egenvärld. Studiens respondenter befinner sig i centrum av modellen. Närmast mitten finns de tre teman som främst utgår från dem som person, det personliga och det de gör, nämligen studerades egenvärld, teknologisk-estetisk värld och kommande lärarens egenvärld. I modellen representerar respondenterna både den studerande och den kommande läraren. Medvärlden innefattar i sin tur inte endast respondenterna själva, utan temat inkluderar slöjdsituationen och andra personer som är delaktiga i situationen. Omvärlden handlar om det respondenterna erfarit som har koppling till det omgivande samhället. Modellen går gradvist från det personliga till det omgivande samhället och världen. Figur 1 visualiserar modellen med de fem temana.

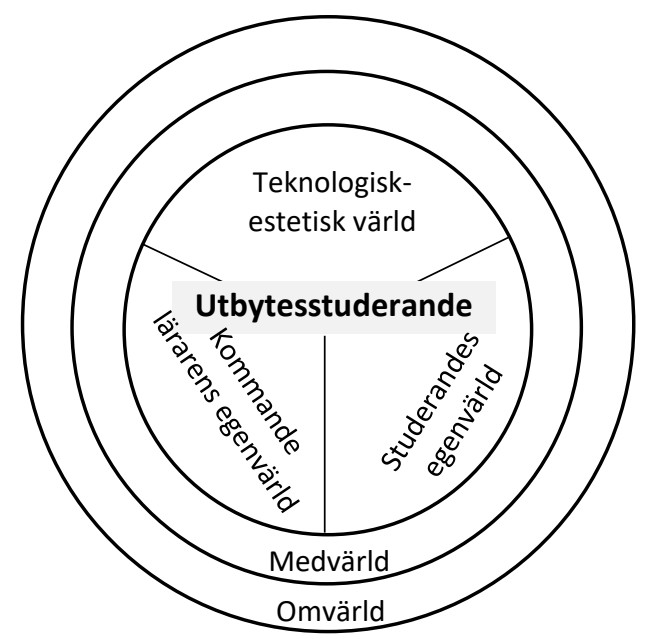

Figur 1. Tematiska analysens fem teman (bearbetad efter Hartvik, 2013, s. 84).

I analysens fjärde fas granskades att alla fem teman fungerar både tillsammans med utdragen som blivit kodade och med hela datamaterialet. Huruvida samma textavsnitt kan kodas in i flera olika teman eller ej är en fråga som forskaren själv behöver ta ställning till (Joffe \& Yardley, 2004). I denna studie har ibland samma textavsnitt kodats in i flera olika teman. I fas fem bearbetades temanamnen och beskrivningar skapades för varje tema. I den sjätte fasen gjordes den slutliga analysen och rapporten. 


\section{Resultat}

Resultaten redovisas utgående från de fem tidigare nämnda temana. Inledningsvis kan konstateras att alla respondenter har erfarenheter som berör studerandes egenvärld, teknologisk-estetisk värld, medvärld och omvärld. Kommande lärarens egenvärld är däremot ett tema som alla inte berör. Instruktionerna för reflektionerna var relativt öppna, vilket resulterade i att det finns stor variation $\mathrm{i}$ längden och karaktären på respondenternas texter. En del har fokuserat på att reflektera kring det som efterfrågades. Andra har valt att skriva reflektioner även för sådant som inte var obligatoriskt. En del har skapat en personlig idébank genom att också beskriva vilka material och redskap som behövs och gjort arbetsbeskrivningar för olika produkter och uppgiftsdelar.

\section{Studerandes egenvärld}

Det första temat, studerandes egenvärld, innefattar sådant som berör respondenterna som person och respondenternas upplevelser av personlig utveckling, exempelvis att utveckla sitt tålamod, självförtroende och finmotorik, samt få mer kontroll över kroppen.

I was working by myself with no one looking and judging what I was doing and that was a good way also to prove myself that I could accomplish good things (even if it takes hours and hours of work). S11

During this project, I learned about persistence through struggles, which I had never dealt with when it comes to handicraft work. I feel like struggling with writing a paper or reading an assignment is much different than struggling with tangible items because not only do you need to think about why something is not working, but you actually have to physically fix the issue instead of writing about it. S4

Citaten ovan kan tolkas som att självförtroendet hos studerande 11 ökade, när hen genom självständigt arbete kunde bevisa för sig själv att hen kan uppnå bra saker. Studerande 4 anser i sin tur att hen fick öva sin uthållighet i samband med problem i en uppgift. Hen jämför skillnaden mellan problem i en praktisk uppgift och i en skriftlig uppgift, vilket kan tolkas som att hen fått ny insikt gällande problemlösning. Utöver det här finns upplevelser av att en respondent känner att hens sinne har ändrats, eller att förmågan att tillämpa tankar har utvecklats. Till temat hör många utsagor som ger uttryck för vad respondenterna känt under kursen. Det här kan vara i relation till specifika uppgifter och produkter, tekniker, lektionstillfällen eller kursen som helhet. Det är sådant som exempelvis har upplevts som roligt, spännande, utmanande eller berikande för respondenterna. Respondenterna uttrycker även att de känt stolthet, nervositet eller nöjdhet i samband med olika situationer, och att de tycker om eller älskar något specifikt med kursen. Citaten nedan visar exempel på hur känslor kommit i uttryck i respondenternas texter. Studerande 2 har känt att det varit både frustrerande och mödosamt att tälja, medan studerande 3 kände en viss nervositet inför att arbeta vidare utan lärare. Studerande 5 och 8 uttrycker i sin tur mer positiva känslor, både för kursen som helhet och för att slöjda i skogen.

As for the knife, it is a task that has frustrated me a lot because it is not something that has been given well to me. I found it a very difficult task to carry out and very laborious [...]. S2

I was a little bit nervous to do it without a teacher but I was able to finish my cookie cutter. S3

All sloyd classes were really significant for me. S5

$[\ldots]$ it was precious experience for me to make something in the forest and I was enjoying it. S8

\section{Teknologisk-estetisk värld}

I det andra temat, teknologisk-estetisk värld, framkommer erfarenheter som kan knytas till planerande och genomförande av olika slöjdtekniker och att arbeta med olika material. Det som framkommer om planering handlar främst om insikten att en plan eller tidtabell kan och får ändras under processens gång. Det finns många erfarenheter av att respondenterna lärt sig olika tekniker under kursen. Det finns också många tekniker och moment $\mathrm{i}$ arbetet som inneburit "first time" erfarenhet för respondenterna, exempelvis beskriver studerande 12 att det var något helt nytt för hen att arbeta med metall. I motsats till det här finns det tekniker som en del respondenter testat på tidigare, exempelvis beskriver studerande 
1 täljning som något lätt, i och med att hen gjort liknande tidigare. Vidare upplever en del respondenter att de haft möjlighet att utveckla och bredda ämneskunskaper som de haft sedan tidigare.

Förutom upplevelser av att ha lärt sig tekniker, har respondenterna också erfarit olika typer av svårigheter och problem i samband med slöjdtekniker och uppgifter. I många fall där respondenterna uttrycker att det varit svårt att genomföra en uppgift eller en teknik, uttrycker de även att det varit roligt, eller att de trots det är nöjda över hur resultatet började se ut och hur produkten blev. Det här tyder på att de inte blivit nedstämda av upplevda svårigheter. I temat framträder att respondenterna har upplevt en del tekniker som lättare än förväntat, medan en del tekniker har upplevts som svårare än förväntat. Exempel på de här sakerna syns i citaten av studerande 3 och 4 här nedanför.

All these things weren't as easy as they looked like but after a while I did it and I had a lot of fun. S3

I had a difficult time beginning because even if I watch the stitches on the example, I have to actually do them to understand what is going on. S4

I samband med tekniker framkommer också utsagor som berör användningen av olika maskiner inom slöjden. Respondenterna upplever att i Finland används maskiner som de själva benämner som farliga. I samband med tankar om tekniker och maskiner, framkommer erfarenhet av att säkerheten är en viktig del av slöjden. Genom att följa lärarens instruktioner är risken för olyckor mindre. Citaten nedan visar hur både studerande 8 och 9 uttrycker tankar om vad som kan vara farligt, men som genom tydliga instruktioner kan göras säkert. Studerande 8 uttrycker dessutom att hen förstår mervärdet $i$ att använda olika maskiner, även sådana som kan uppfattas som farliga. Vidare upplever en del av respondenterna att de inte alltid hann bli klara med uppgifter under den lektionstid som gavs för respektive uppgift. I samband med det här dras det ofta kopplingar till att de är ovana slöjdare och att andra var snabbare.

Also, I felt it is dangerous for children using machines such as cutting machine, but I understood they need to learn how to use them in safe way and it makes the class more practical. S8

At the beginning I thought it [arbete med bleckplåt] could be eve dangerous, but when you follow the teacher's advice it is very complicated to have an accident. S9

\section{Kommande lärarens egenvärld}

Det tredje temat, kommande lärarens egenvärld, handlar om sådant som tangerar erfarenheter som respondenterna tar med sig inför att de själva blir lärare, eller inför arbete med barn. Det här berör saker eller uppgifter som de tänker att de har nytta av eller som de vill använda som lärare, exempelvis specifika tekniker och uppgifter från kursen. I citaten nedan syns det hur studerande 13 upplever att temat "I sagornas värld" är något som kunde fungera också med elever. Till skillnad från studerande 13 som ser till ett specifikt tema, reflekterar studerande 11 på ett mera allmänt plan kring vad hen tar med sig till sitt kommande yrke. Där är det kursens innehåll och förfaringssätt som helhet som fungerar som inspiration inför kommande läraryrke.

This theme is really suitable for kids in school too. They could choose their favorite fairy tale and make for example a requisite for it $\mathrm{S} 13$

The benefits this course bring are huge and as a teacher in [hemlandet] I will try to use the principles of this course with my class. S11

Respondenterna har utgående från kursen och dess upplägg, fått tankar och idéer om hur de själva kan planera undervisning och uppgifter med tanke på att öka samarbetet, samt hur kreativiteten kan gynnas i en uppgift om ramarna är relativt öppna. Citatet nedan visar hur studerande 9, i samband med "I sagornas värld", insåg hur kreativiteten kan gynnas genom upplägget på en uppgift. Den här insikten kan tänkas vara något som hen också tar med sig i framtiden, $\mathrm{i}$ och med att hen uttrycker det på ett positivt sätt i reflektionerna. 
With this project [I sagornas värld] I have realized that it is much better to ask for something very opened, before to put very rule. It is great for the creativity. S9

Avslutningsvis hör till temat sådana utsagor som består av reflektioner utgående från (kommande) elevperspektiv, exempelvis att vid arbete med barn är säkerheten viktig, och att det är viktigt att barn får uppleva naturen och utveckla finmotoriken. Exempel på hur en lärare kan agera är något som en respondent lyfter fram att hen fått modell för under kursen. Sådana här reflektioner har sin utgångspunkt i något som respondenterna erfarit under kursen. Exempelvis visar citatet av studerande 12 på hur hen, med utgångspunkt i utedagen, reflekterar kring vad hen anser vara viktigt vid arbete med barn; kontakt med naturen och utvecklande av finmotorik. Citatet visar även att hen kopplar ihop tidigare kunskaper och erfarenheter med det som hen erfarit under slöjdkursen. Gardners teorier behandlades nämligen inte under slöjdkursen utan det är sådana kunskaper hen har sen tidigare.

I think the Christmas wreath involves a more direct contact with nature, which I consider extremely important when working with children. As a future teacher I give much importance to Gardner's multiple intelligences Theory and I think naturalistic intelligence is one of the most frequently forgotten and we must work to change that. Also, in a motor level, I concider that be able to braid and carve involves the development of fine motor skills, which is also an important aspect to be developed in kids. S12

\section{Medvärld}

Det fjärde temat, medvärlden, handlar om respondenternas erfarenheter av samarbete, kontakt och interaktion med medstuderande och lärare. Hit hör erfarenheterna av att få diskutera, lära känna och umgås med andra studerande på kursen. Vidare ingår erfarenhet av att uppmanas att samarbeta och att lära sig saker av medstuderande, både när det gäller slöjdspecifikt innehåll och sådant som berör andras kulturer. Respondenterna upplever även att de under kursen fătt lära sig att kommunicera över språkoch kulturgränser, i och med att medstuderandena kom från helt olika bakgrunder. En respondent framhåller också att slöjdkursen var enda kursen med finländska studeranden som hen deltog i.

Firstly, we made fire and ate something, what was nice, because we got in contact with all the other students we didn't know until now. S1

We had to tie a knot by team. That was quite a funny experience since we were forced to learn how to communicate inspite of our cultural, language and age differences. We continued the hike which lead to real and good discussions with some of my classmates. S11

I do not work as fast as many of the others do, and especially since I was in the Swedish group, I was lost for a while. After working on it a bit more, I was able to get help from the others in my group, particularly in the embroider part since I was confused about the stitches. S4

I citaten ovan framkommer exempel på hur studerande 1 och 11 upplever interaktionen och kommunikationen med medstuderande som något positivt och roligt. Det framgår också hur de fick möjlighet att lära känna personer som de inte var bekanta med sedan tidigare. Diskussionerna kan tolkas som viktiga och värdefulla i och med att de beskrivs som både "real och "good". I citatet av studerande 4 framkommer det hur hen jämför sig med andra och hur hen fătt hjälp av andra på kursen. I samband med erfarenheter som berör medstuderanden finns det en kategori med utsagor som handlar om att respondenterna jämför sig med andra på kursen. Jämförelserna handlar ofta om att respondenten upplever att hen inte är lika snabb som andra, samt att andra kunnat göra mer avancerade saker. När det kommer till samarbete finns det förutom erfarenhet av att hjälpa varandra, även erfarenhet av att det stundvis kan vara en utmaning. Studerande 3 anser att grupparbete alltid är lite svårt, men beskriver hur de inom gruppen diskuterat och gett förslag för att lösa problem som uppstått. Hen har upplevelse av att det varit aningen svårt att arbeta med en person som var frånvarande i början. Det resulterade i att gruppen upprepade gånger behövde förklara deras skiss för personen. I gruppen blev det aningen stressigt, i och med att alla medlemmar inte följde tidsplanen de kommit överens om. 
Temat medvärlden handlar inte endast om relationer, utan inkluderar också erfarenheter som hänger ihop med undervisningsarrangemang och -situationer. Som exempel kan nämnas att respondenterna upplever att de erbjudits valmöjligheter, som inneburit möjlighet att genomföra personligt utformade projekt. Ett annat exempel är erfarenheten av att få ansvar och förtroende att vistas i slöjdsalarna utanför schemalagd undervisningstid. Många upplevelser och utsagor hör ihop med specifika lektionstillfällen, såsom utedagen och tillfället då gruppen bakade med hjälp av formarna de tillverkat. I citaten nedan framkommer hur studerande 12 upplever att lektionsupplägget var sådant, att hen lätt kunde följa med fastän de olika processerna var nya. De kunde räkna med lärarens handledning när det behövdes. Studerande 10 önskar i sin tur att de skulle fått vara delaktiga i hela processen vid pepparkaksbakningen och inte endast i att baka ut degen. Det här visar att själva undervisningsarrangemanget och -situationen på olika sätt påverkar erfarenheterna och upplevelserna.

That is why all the processes involved in the Sloyd classes are kind of new to me personally. But it wasn't hard to follow the flow of the classes since every step is well explained, the objectives and the procedures re in-depth detailed and if we have any problem we can always count on the teachers. S12

Making ginger bread was fun. [...] However, it's better to make them from the start because what we need to do was only cut them out with cookie cutter, put them in the oven and wait till ready. Except it, it was an exciting experience. $\mathrm{S} 10$

\section{Omvärld}

Det femte temat, omvärlden, handlar om de erfarenheter som inte endast fokuserar på det som sker just där och då under kursen. Temat fokuserar på sådant som berör samhället och en större helhet utanför kursen. Här handlar det till exempel om respondenternas jämförelse mellan hemlandet och Finland när det gäller slöjdämnet, både hur upplägget ser ut och vilken roll slöjden har. Det som framkommer i sådana jämförelser är främst att respondenterna upplever att slöjden, eller ett liknande ämne, har en större roll i Finland än i hemlandet. Hemlandet erbjuder inte heller lika mycket frihet inom liknande ämnen. Skillnaden i friheten handlar både om möjligheterna att vistas i slöjdsalarna och möjligheterna att påverka produkterna som planeras och tillverkas. Det här är sådant som tydligt framkommer i citaten nedan.

Finally, I can say that I enjoyed the course. It was nice to see how you work in Finland. Because in [hemlandet] we never can work in our free time on our own in the sloyd rooms - there should be always a teacher, also in the university. S1

It was such a great experience to take the course and good opportunity to compare with our technology education which is similar to sloyd and Finnish sloyd education. Sloyd is a mix of home economic class and technology class in my country. [...] Things we do in the class are actually quite similar, but the style and value are pretty different. In my country, those classes are not considered as important subjects because they are not for entrance exams of high school or university. S6

Till temat hör också deras erfarenhet av att ha fått kunskap om olika länder och kulturer, både när det kommer till slöjdämnet, och på ett mera allmänt plan. De här utsagorna är delvis sådana som finns i både medvärlden och omvärlden. De knyter an till medvärlden i och med att de ofta utgår från kursens undervisning och upplägg. Samtidigt knyter de an till omvärlden för att de består av reflektioner som berör ett större sammanhang. Som det framgår av citatet nedan, kopplar exempelvis studerande 2 en kursuppgift som ett trevligt minne av tiden i Finland och universitetskulturen som finns här. Själva kursuppgiften och tankarna kring den hör till medvärlden. Sedan går det in i omvärlden när reflektionen berör den finländska universitetskulturen, för då handlar reflektionen inte längre om innehållet i den specifika slöjdkursen.

I really liked that this work was proposed since it will also be a patch that I will put on my overall and it will be a very nice memory of the first time I practiced sewing and my experience in Finland since it is representative of the universities here. S2 
Till det här temat hör även respondenternas upplevelser av koppling till den egna kulturen och bakgrunden. Dels väcks barndomsminnen till liv i uppgifter, som för studerande 3, dels upplever respondenterna att de haft möjlighet att uttrycka och presentera den egna kulturen för medstuderanden, som det framkommer i citatet av studerande 5 .

It really reminded me of times when I was a kid, because I did it [armband] at many birthday parties. S3

About a finished product [broderat märke], it looks a little bit ugly, but I think I can express the great nature of my hometown. S5

Vidare hör till det här temat tankar som visar på att respondenterna upplever sig ha fått en större insikt i tillverkning av produkter på ett mera allmänt plan. Studerande 10 reflekterar inte endast kring den specifika produkten hen tillverkat, utan kopplar det till vilka möjligheter som finns, om man har rätt kunskaper. Genom att ha lärt sig hur svårt det är att göra en kudde, känner hen respekt för de som tillverkar olika produkter.

Through this project [I sagornas värld], I learned that I could make almost of things around me, if I had appropriate knowledge and skills. At the same time, I learned that how hard to make just one cushion was. So, I never forget the respect for who makes these products. S10

Slöjd is undoubtably one of the reasons why the school system is the best in Finland. S11

Citatet av studerande 11 här ovan, visar avslutningsvis på att det också framkom kraftfulla utsagor med tankar om vilken betydelse som slöjd har för den finländska skolan. En sådan kraftfull utsaga som studerande 11 har tyder på att slöjdkursen gjort ett positivt intryck med tanke på hur hen valt att formulera sig.

\section{Diskussion}

Som det framkommer i tidigare studier (Sato \& Hodge, 2015), berör erfarenheter från utbytestiden både det personliga och det akademiska planet. Erfarenheterna i den här studien utgår från det akademiska planet eftersom utgångspunkten är en kurs som respondenterna valt att avlägga som en del av sina utbytesstudier. Samtidigt går erfarenheterna in på det personliga planet. Som det framkommer i resultaten handlar speciellt temat studerandes egenvärld om det personliga, med innehåll som tar fasta på respondenternas känslor och upplevelse av personlig utveckling. Respondenterna lyfter fram glädje, frustration, stolthet och känsla av att ha utvecklat både finmotorik och självförtroende. Det att respondenterna synliggör att de utvecklats som människa, överensstämmer med tidigare studier (Nilsson, 2015). Det här kan även hänföras till det som Huovila och Rautio (2008) lyfter fram, att slöjden ska ha som mål att skapa känsla av glädje och tillfredsställelse över arbete och att självkänslan ska växa.

Som det konstaterats kan utbytesstuderande uppleva olika typer av akademiska utmaningar, exempelvis språkproblem (Garam, 2001; Mesidor \& Sly, 2016; Sato \& Hodge, 2015). Bland studiens respondenter framkommer en del problem i relation till kursen. Inga av dessa upplevelser handlar om språkproblem, utan här är problemen främst kopplade till olika uppgifter och slöjdtekniker som respondenterna kommer i kontakt med under kursen. Det är främst på det ämnesteknologiska planet som problemen framkommer. De här problemen hänger ofta samman med att teknikerna och materialen är nya för många av respondenterna. Det faktum att kommunikationen i slöjd inte endast är verbal (Andersson \& Johansson, 2017; Degerfält \& Porko-Hudd, 2008; Hartvik, 2013; Illum \& Johansson, 2009) kan vara en bidragande faktor till att det inte framkommer upplevelser av språkproblem.

Sato och Hodge (2015) lyfter fram hur kulturella skillnader, mellan hemlandet och det mottagande landet, kan resultera i studiesvårigheter. Även i denna studie kan det urskiljas att det finns erfarenheter som handlar om kulturella skillnader i undervisningssättet och universitetskulturen. Däremot är skillnaderna inte kopplade till svårigheter med studierna, utan snarare kan erfarenheterna tolkas som något positivt i och med att det handlar om respondenternas erfarenhet av att få möjlighet, ansvar och 
förtroende att arbeta i slöjdsalarna utanför schemalagd lektionstid, något som inte hör till universitetskulturen i deras hemländer. Vidare finns det skillnader i formulering av uppgifter. I Finland upplever respondenterna att de har större frihet och påverkningsmöjlighet $\mathrm{i}$ vad de gör. Dessa upplevelser framträder i sådana sammanhang att de kan tolkas som positiva.

Kulturella skillnader finns också i hur slöjdämnet uppfattas i olika länder. Erfarenheterna av att slöjd har en annorlunda roll och högre status i Finland, än ett liknande ämne i hemlandet, är liknande som de erfarenheter Kokko och Dillon $(2011 ; 2016)$ lyfter fram i sin forskning. Andra likheter med det som Kokko och Dillon lyfter fram, är respondenternas önskan om att slöjdämnet och dess arbetssätt $i$ högre grad skulle finnas i deras hemländer. Tankar om att implementera innehåll från slöjdkursen i hemlandets skolor visar på att slöjdens innehåll uppfattas som värdefullt. Tanken om att implementera erfarenheterna hemma rör inte enbart slöjdtekniker, utan det rör också arbetssätt och uppgifter som de erfarit under kursen. Även tankar om vad som är viktigt vid arbete med barn framkommer. Erfarenheter som de vill ta med sig hem är därför sådant som ingår i kommande lärarens egenvärld. Resultaten har likheter med det som Pöllänen och Vartiainen (2013) lyfter fram i sin forskning om klasslärarstuderandes erfarenheter av lärande i samband med ett grupprojekt i slöjd. Likheter, som kan urskiljas, är bland annat att respondenterna i båda studierna har upplevelser av att ha utvecklats och fått tankar gällande samarbete, kommunikation och självstyrning, när det kommer till arbete med elever. Det här visar på att erfarenheter kopplade till läraryrket till vissa delar kan vara liknande, även om respondenternas slöjdbakgrunder är olika.

Inom medvärlden handlar erfarenheterna mycket om sådant som har att göra med interaktionen och kontakten med medstuderanden. Det här har likhet med andra studier (Garam 2001; Hietaluoma, 2001; Sato \& Hodge, 2015), där det framgår att erfarenhet av olika relationer är något som finns bland utbytesstuderande. Positiva erfarenheter av social interaktion i samband med slöjdverksamhet är också sådant som framkommer i tidigare forskning (Kouhia, 2015). Att respondenterna valt att beskriva och lyfta fram sådant som har att göra med relationer, kan hänga ihop med om de haft förväntningar på att skapa nya kontakter under utbytestiden. Förväntningar är ingenting som efterfrågats och undersökts i den här studien, men bland annat Costas och Singco (2016), Hietaluoma (2001) samt Sato och Hodge (2015) lyfter fram att nya kontakter är en förväntning som brukar finnas inför utbytesstudier. I den här studien kan respondenternas upplevelser av relationerna tolkas som positiva. Att interaktionen och samarbetet med andra kan ses som något viktigt och positivt för utbytesstuderande stämmer även med det som Kröger (2020) lyfter fram i sin forskning. Det framkommer inga negativa upplevelser, bortsett från att en respondent upplevde vissa problem med att samarbeta. Där handlade det främst om att en gruppmedlem hade varit borta när grupparbetet inleddes och därför försvårades samarbetet. Att grupparbete kan vara krävande är något som även Pöllänen och Vartiainen (2013) lyfter fram. Relationer till lärarna nämns inte i någon större utsträckning, men det som framkommer är att en respondent upplevde att lärarna fanns där, när det behövdes. Det här uttalandet visar på likhet med det som Hietaluoma (2001) och Garam (2001) lyfter fram om att utbytesstuderande i Finland upplevt att kontakten till personalen är enkel och att både personal och medstuderande är hjälpsamma. Att få och ge hjälp, av och åt medstuderande är aktuella erfarenheter i den här studien. Av respondenternas texter framgår det inte i större utsträckning om interaktionen med medstuderande främst har varit med andra utbytesstuderande eller med finländska studerande. Det som ändå framkommer är att för en av respondenterna var slöjdkursen enda kursen hen deltog i med även finländska studerande. Det här ger indikationer på att det, i likhet med vad Garam (2001) lyfter fram, kan vara svårare för utbytesstuderande att komma i kontakt med lokala studerande, bland annat för att utbytesstuderande ofta avlägger kurser där det nödvändigtvis inte deltar lokala studeranden.

I motsats till upplevelser som Sato och Hodge (2015) lyfter fram om att utbytesstuderande känner sig isolerade i samband med gruppdiskussioner, framkommer inga sådana indikationer bland 
respondenterna. I samband med att de ombads reflektera kring samarbetet inom sista kurstemat, framkommer det istället positiva upplevelser om att de kunnat diskutera sig fram till olika lösningar. Det här kan ses som något som hör ihop med hur Kröger (2012) beskriver att ett slöjdföremål kan underlätta kommunikationen för personer med olika bakgrunder. Genom samarbete upplever respondenterna att de kunnat dra nytta av den kunskap som fanns inom gruppen. Upplevelse av att samarbete stöder utvecklingsprocessen är sådant som även Pöllänen och Vartiainen (2013) lyfter fram i sin studie. Respondenterna i respektive studier ser vilka möjligheter det finns i att dra nytta av kunskaper som finns inom en grupp i samband med grupparbete. I den här studien lyfter en respondent fram att speciellt en av de finländska studerandena kunde mycket. I båda studierna upplever respondenterna att de har utvecklat sin kommunikationsförmåga genom samarbete med andra. Samarbetet och interaktionen med personer från olika länder resulterar i upplevelser av att lära sig om andra kulturer och andra länders traditioner. Det här kan kopplas till liknande förväntningar som finns inför ett utbyte, och som framkommer i andra studier (Costas \& Singco, 2016; Hietaluoma, 2001). De här erfarenheterna speglar även det som Kröger (2012) lyfter fram om att slöjd kan fungera som ett redskap för att möjliggöra mångkulturell kommunikation och för att förstå skillnader.

Avslutningsvis kan det konstateras att de erfarenheter som respondenterna lyfter fram till stor del berör liknande områden som framkommit i tidigare studier om studerandes erfarenheter av utbyte. Fokus finns inom det personliga och det sociala. På alla områden har erfarenheterna inte varit av samma karaktär som i tidigare studier, men i de fallen har erfarenheterna istället kunnat hänföras till slöjdämnets karaktär, och även relateras till tidigare forskning om erfarenheter i slöjd. De erfarenheter som framkommer i resultaten och som mest skiljer sig från tidigare forskning om erfarenhet av utbytesstudier, är att det bland den här studiens respondenter inte framkommer upplevelser av språkproblem eller av akademiska utmaningar. Möjligheten till interaktion och olika kommunikationssätt i slöjd kan ses som en viktig aspekt, och som medför något positivt för utbytesstuderande som deltar i slöjdkurser. De positiva erfarenheterna från slöjdkursen handlar mycket om att undervisningen var sådan som möjliggjorde, och även förutsatte interaktion mellan studerande. Att få diskutera med, lära känna och samarbeta med medstuderande är sådant som framkom på många olika sätt och kan ses som viktigt för utbytesstuderande. Därför är det en sak som också är viktigt och bra för universiteten att vara medvetna om och beakta vid planerandet av kurser för utbytesstuderande. En fördel är ifall det i kurser går att integrera utbytesstuderande med lokala studeranden, vilket var möjligt i den aktuella slöjdkursen. Genom att dessa saker beaktas kan utbytesstuderandes möjligheter till positiva erfarenheter av utbyte främjas. Den här studien har enbart fokuserat på utbytesstuderandes direkta erfarenheter från en slöjdkurs, utan en djupare redogörelse av deras tidigare erfarenheter av och kunskaper i ämnet. För att få en bredare bild av temat, skulle det i vidare forskning kunna fokuseras på dels utbytesstuderandes tidigare erfarenheter av slöjd, dels vilka minnen och spår som finns kvar efter att de lämnat slöjdkontexten och återvänt till sitt hemland.

\section{Referenser}

Ahlskog-Björkman, E. (2007). Textilt skapande som estetisk-etisk transformation: Om medierat lärande $i$ vårdutbildning (Akademisk avhandling). Åbo: Åbo Akademis förlag.

Alvesson, M. \& Sköldberg, K. (2008). Tolkning och reflektion: Vetenskapsfilosofi och kvalitativ metod. Lund: Studentlitteratur.

Andersson, J. \& Johansson, M. (2017). Learning situations in Sloyd. To become more handy, dexterous and skilful. Techne serien - Forskning i Slöjdpedagogik och Slöjdvetenskap, 24(2), 93-109.

Anttila, P. (2005). Tutkiva toiminta ja ilmaisu, teos, tekeminen [Forskande verksamhet och uttryck, verk, görande]. Hamina: Akatiimi.

Bista, K. (2019). Exploring the field: Understanding the international student experience. I K. Bista (red.), Global perspectives on international student experiences in higher education: Tensions and issues (s. 1-16). New York: Routledge https://doi.org/10.4324/9781315113456-1 
Braun, V. \& Clarke, V. (2006). Using thematic analysis in psychology. Qualitative Research in Psychology 3(2), 77-101. https://doi.org/10.1191/1478088706qp063oa

Costas, A. C. \& Singco, J. K. (2016). Experienes of Japanese exchange students in a Cebuano university. University of the Visayas - Journal of Research, 10(1), 115-122.

Degerfält, I. \& Porko-Hudd, M. (2008). Informationsteknik - ett redskap i söjden. I K. Borg \& L. Lindström (red.), Slöjda för livet. Om pedagogisk slöjd (s. 113-123). Stockholm: Lärarförbundet.

Garam, I. (2001). My Finland: Selvitys ulkomaisten vaihto-opiskelijoiden kokemuksista suomalaisissa korkeakouluissa [Mitt Finland: En utredning om utländska utbytesstuderandes erfarenheter från finländska högskolor]. Helsinki: Kansainvälisen henkilövaihdon keskus CIMO.

Garam, I. (2018). Facts Express 6B/2018: What brought students to Finland, how do they find studying here? Helsingfors: Utbildningsstyrelsen.

Geary, D. (2016). How do we get people to interact? International students and the American experience. Journal of international students, 6(2), 527-541. https://doi.org/10.32674/jis.v6i2.369

Hartvik, J. (2013). Det planlagda och det som visar sig. Klasslärarstuderandes syn på undervisning i teknisk slöjd. (Akademisk avhandling). Vasa: Åbo Akademis förlag.

Hellstén, M. \& Prescott, A. (2004). Learning at University: The International Student Experience. International Education Journal, 5(3), 344-351.

Hietaluoma, H. (2001). Why Finland. Selvitys ulkomaisten vaihto-opiskelijoiden hakeutumisesta suomalaisiin korkeakouluihin[Varför Finland. Utredning om utländska utbytesstuderandes ansökan till finländska högskoloro]. Helsinki: CIMO Publications.

Huovila, R. \& Rautio, R. (2008). Käsiksi käsityönopetukseen - nelikenttä käsityönopettajan ja opettajankouluttajan työvälineenä [Greppa slöjdundervisningen - fyrfältaren som lärarens och lärarutbildarens redskap]. I P. Kaikkonen (Red.), Työ haastaa tutkimaan. Opettajien arkihavainnoista kokonaisuuksien ymmärtämiseen. (s. 125-140). Jyväskylä: Jyväskylän yliopisto.

Illum, B. \& Johansson, M. (2009). Vad är tillräckligt mjukt? - kulturell socialisering och lärande i skolans slöjdpraktik. FORMakademisk, 2(1), 69-82. https://doi.org/10.7577/formakademisk.62

Joffe, H. \& Yardley, L. (2004). Content and thematic analysis. I D. F. Marks \& L. Yardley (red.), Research method for clinical and health psychology (s. 56-68). London: Sage.

Kokko, S. \& Dillon, P. (2011). Crafts and craft education as expressions of cultural heritage: individual experiences and collective values among an international group of women university students. International Journal of Technology and Design Education, 21, 487-503. https://doi.org/10.1007/s10798-010-9128-2

Kokko, S. \& Dillon, P. (2016). Engagin trainee teachers with crafts and cultural heritage. International Journal of Education trhrough Art, 12(1), 21-37. https://doi.org/10.1386/eta.12.1.21_1

Kouhia, A. (2015). Crafting the collective sense: A descriptive case study on recreational textile craft-making in Finnish adult education. International Journal of Education Through Art, 11(1), 7-20. https://doi.org/10.1386/eta.11.1.7_1

Kröger, T. (2012). Sulautuvaa opetusta moni- ja interkulttuurisen käsityön kurssilla [Blended learning i en mång- och interkulturell slöjdkurs]. Yliopistopedagogiikka, 19(1), 18-21.

Kröger, T. (2020). Promoting significant learning in a cultural craft course. Craft Research, 11(2), 211-236. https://doi.org/10.1386/crre_00026_1

Lindfors, L. (1991). Slöjdverksamhetens grunddimensioner vid arbetsinlärning $i$ ett slöjdpedagogiskt perspektiv. (Rapporter från pedagogiska fakulteten vid Åbo Akademi 33/1991) Vasa: Åbo Akademi.

Mesidor, J. K. \& Sly, K. (2016). Factors that Contribute to the Adjustment of International Students. Journal of International Students, 6(1), 262-282. https://doi.org/10.32674/jis.v6i1.569

Nilsson, P. A. (2015). Expectations and Experiences of Inbound Students: Perspectives from Sweden. Journal of international students, 5(2), 161-174. https://doi.org/10.32674/jis.v5i2.432

Nowell, L. S., Norris, J. M., White, D. E. \& Moules, N. J. (2017). Thematic Analysis: Striving to Meet the Trustworthiness Criteria. International Journal of Qualitative Methods, 16, 1-13. https://doi.org/10.1177/1609406917733847

Oja, M., Sjöberg, B. \& Johansson, M. (2014). Kommunikationens inbäddade resurs för lärande i slöjdundervisning. Forskning om undervisning och lärande, 12(1), 5-20.

Porko-Hudd, M. (2005). Under ytan, vid ytan och ovanför ytan. Analys avtanken bakom tre läromedel i slöjd (Akademisk avhandling). Åbo: Åbo Akademis förlag. 
Pöllänen, S. \& Vartiainen, L. (2013). Forest-themed learning games as a context for learning via collaborative designing of crafts. Techne serien - Forskning i slöjdpedagogik och slöjdvetenskap, 20(3), 33-49.

Sato, T. \& Hodge, S. R. (2015). Japanese Exchange Students' Academic and Social Struggles at an American University. Journal of International Students, 5(3), 208-227. https://doi.org/10.32674/jis.v5i3.417

Sjöberg, B. (2009). Med formgivning i fokus. En studie om holistisk slöjd i lärarutbildningen (Akademisk avhandling). Åbo: Åbo Akademi.

Studiehandboken. (u.å.). 660001.2 Slöjdkunnande, 5 sp. Hämtad från https://studiehandboken.abo.fi/sv/course/660001.2/1955

Undervisnings- och kulturministeriet (2017a). Bäst $i$ världen tillsammans. Riktlinjer för att främja internationaliseringen av finländsk högskoleutbildning och forskning 2017-2025. Hämtad 6 maj 2019, från https://minedu.fi/documents/1410845/4154572/YMP-sv-net.pdf/995fd2e2-14ff-4c07-aff67abf72db27b5/YMP-sv-net.pdf.pdf

Undervisnings- och kulturministeriet (2017b). Yhteistyössä maailman parasta. Suomalaisen korkeakoulutuksen ja tutkimuksen kansainvälisyyden edistämisen linjaukset 2017-2025 [Bäst i världen tillsammans. Riktlinjer för att främja internationaliseringen av finländsk högskoleutbildning och forskning 2017-2025], Undervisnings- och kulturministeriets publikationer 2017:11. Hämtad 7 maj 2019, från http://julkaisut.valtioneuvosto.fi/bitstream/handle/10024/79438/okm11.pdf?sequence=15\&isAllowed=y

Vipunen (u.å.). Utbildningsförvaltningens statistiktjänst. Hämtad 26 februari 2021, från https://vipunen.fi/fifi/_layouts/15/xlviewer.aspx?id=/fi-fi/Raportit/Yliopistojen\%20tutkintoopiskelijoiden\%20kansainv\%C3\%A4linen\%20liikkuvuus\%20-\%20yliopisto.xlsb

Westerlund, S. (2015). Lust och olust - elevers erfarenheter i textilslöjd (Akademisk avhandling). Umeå: Umeå Universitet: Institutionen för estetiska ämnen.

Westlund, I. (2019). Hermeneutik. I A. Fejes \& R. Thornberg (red.), Handbok i kvalitativ analys (s. 72-90). Stockholm: Liber.

Pia Brännkärr, PeM, universitetslärare och doktorand inom slöjdvetenskap vid Åbo Akademi i Vasa, Finland. Brännkärr undervisar inom textilslöjd för ämneslärar- och klasslärarstuderanden. Hon handleder även kandidatarbeten och praktik i anslutning till lärarutbildning. Hennes forskningsintresse är utbytesstuderande och deras möte med slöjd inom skola och utbildning. 